\title{
A New Ursane-Type Triterpene from the Fermented Shallot Allium Ascalonicum
}

\author{
Nguyen Van Chuyen\#, Nguyen Hong Son\#, Pham Van Hien, Dang Truong Giang, Ho Ba Ngoc Minh, Ngo Thi \\ Tuyet Mai, Chu Van Men, Ho Anh Son*, Vu Binh Duong*
}

Nguyen Van Chuyen", Nguyen Hong Son", Pham Van Hien, Dang Truong Giang, Ho Ba Ngoc Minh, Ngo Thi Tuyet Mai, Chu Van Men, Ho Anh Son*, Vu Binh Duong*

Vietnam Military Medical University, 160 Phung Hung, Ha Dong District, Hanoi, VIETNAM.

\#These authors contributed equally to this work.

\section{Correspondence}

Vu Binh Duong, Ph.D

The Drug R\&D Center, Vietnam Military Medical University, Hadong District, Hanoi, VIETNAM.

Phone no: +84-98251310

E-mail: vbduong2978@gmail.com

\section{Ho Anh Son, Ph.D}

Institute of Biomedicine and Pharmacy, Vietnam Military Medical University, 160 Phung Hung, Ha Dong District, Hanoi, VIETNAM.

Phone no: +84-35-321-2500

E-mail: hoanhsonhp@gmail.com

History

- Submission Date: 29-08-2020

- Review completed: 23-09-2020

- Accepted Date: 01-10-2020.

DOI : 10.5530/pj.2021.13.1

Article Available online http://www.phcogj.com/v13/i1

Copyright

(C) 2021 Phcogj.Com. This is an openaccess article distributed under the terms of the Creative Commons Attribution 4.0 International license.

\section{ABSTRACT}

3,24-acetonideclethric acid (1), a new ursane-type triterpene, and four known compounds including ursolic acid (2), randiasaponin IV (3), ilekudinoside W (4) and (25S)-1 $\beta, 3 \beta, 24 \beta$ trihydroxyspirost-5-en 1-O- $\alpha$-L-rhamnopyranosyl-(1 $\rightarrow 2)$ - $\alpha$-L-arabinopyranoside (5), and were isolated from the fermented shallot Allium ascalonicum. Their structures were determined by analysis of HR-ESI-MS, NMR spectral data, as well as comparison with those reported in the literature. All of the saponins (3-5) exhibited antimicrobial activity against three strains Staphylococcus aureus, Escherichia coli, and Candida albicans with $\mathrm{IC}_{50}$ values in the range from $89.49 \pm 2.24$ to $95.71 \pm 3.86 \mu \mathrm{M}$.

Key Words: 3,24-Acetonideclethric acid, Saponin, Allium ascalonicum, Antimicrobial activity.

\section{INTRODUCTION}

Genus Allium is one of the largest genera of the Amaryllidaceae family. It was reported comprising of more than 800 species and widely distributed throughout temperate regions in the world including Europe, Asia, North America and Africa. ${ }^{1}$ Allium species were also highly regarded worldwide for both therapeutic and culinary values including $A$. cepa (onion), A. sativum (garlic), $A$. porrum (leek), A. schoenoprasum (chive), and A. ascalonicum (shallot). They have been used for thousands of years as flavor-enhancing foods and folk medicines having hypocholesteremic, hypotensive, hypoglycemic, anti-thrombotic, antiallergic, anti-inflammatory, anti-microbial, antifungal, and anti-oxidant activity. ${ }^{2}$ Phytochemical studies suggested that Allium species are rich of sulfur-containing volatile compounds, phenolics, steroids, triterpenes, as well as saponins. The saponins from Allium species were highlighted for their cytotoxic and antimicrobial activity. ${ }^{3,4}$ However, the sulfur compounds responsible features and its distinctive smell. In addition, fermented shallot is delicious. In our research to find new antimicrobial agents from Allium species, herein, we report the isolation, structural elucidation of a new ursane-type triterpene and four known compounds from the fermented shallot $A$. ascalonicum. The anti-microbial activity of isolated triterpenoids and saponins were also evaluated by liquid-dilution method using resazurin as a redox indicator of microbial viability.

\section{RESULTS AND DISCUSSION}

The fermented shallot of $A$. ascalonicum was extracted in methanol, partitioned successively in dichloromethane and ethyl acetate. The crude extracts were separated and purified by combination of various chromatographic technic to obtain 5 compounds (1-5, Figure 1)
Compound $\mathbf{1}$ was isolated as a white amorphous powder. Its molecular formula was determined to be $\mathrm{C}_{33} \mathrm{H}_{52} \mathrm{O}_{6}$ by a quasi-molecular ion peak at $\mathrm{m} / z$ 543.3691 [M-H] (calcd for $\left.\mathrm{C}_{33} \mathrm{H}_{51} \mathrm{O}_{6}, 543.3686\right)$ in the HR-ESI-MS and in conjunction with the ${ }^{13} \mathrm{C}-\mathrm{NMR}$ spectral data. The ${ }^{1} \mathrm{H}-\mathrm{NMR}$ spectrum of $\mathbf{1}$ contained signals for 7 methyl groups $\left[\delta_{\mathrm{H}} 1.40,1.37,1.26,1.19\right.$, $0.91,0.69($ each $3 \mathrm{H}, \mathrm{s})$ and $\left.\delta_{\mathrm{H}} 0.93(3 \mathrm{H}, \mathrm{d}, J=6.8 \mathrm{~Hz})\right]$, five carbinol protons $\left[\delta_{\mathrm{H}} 3.95\left(1 \mathrm{H}\right.\right.$, br s) and $\delta_{\mathrm{H}} 3.87$, $3.73,3.68,3.59$ (each $1 \mathrm{H}, \mathrm{d}, J=6.8 \mathrm{~Hz}$ )], an olefinic proton $\left[\delta_{\mathrm{H}} 5.33(1 \mathrm{H}\right.$, br s) $]$, and a lot of shielded signals in the range $\delta_{\mathrm{H}} 1.02 \sim 2.51$. The ${ }^{13} \mathrm{C}-\mathrm{NMR}$ and HSQC spectra of 1 revealed signal of 33 carbons. Of these, a deshielded signal at $\delta_{C} 183.4$ was assigned for a carbonyl carbon. Two olefinic carbon signals at $\delta_{\mathrm{C}} 137.8$ and 129.3 indicated for the presence of a C-C double bond. An acetal and others four oxygenated carbons were characterized by signals at $\delta_{\mathrm{C}} 98.7$, 73.1, 67.2, 65.0, 64.4. Aforementioned spectral data indicated that compound $\mathbf{1}$ to be a triterpene. Moreover, the NMR data of $\mathbf{1}$ were recognized in close similarity with those of clethric acid ${ }^{5}$ except for the additional signals of an acetonide group $\left(\delta_{\mathrm{C}} 98.7, \delta_{\mathrm{C}} 27.9 / \delta_{\mathrm{H}} 1.37\right.$, and $\left.\delta_{\mathrm{C}} 20.5 / \delta_{\mathrm{H}} 1.40\right)$. The presence of acetonide group was also confirmed by HMBC correlations between $\mathrm{H}_{3}-2^{\prime}\left(\delta_{\mathrm{H}} 1.40\right) / \mathrm{H}_{3}-3^{\prime}$ $\left(\delta_{\mathrm{H}} 1.37\right)$ and $\mathrm{C}-1^{\prime}\left(\delta_{\mathrm{C}} 98.7\right)$ (Figure 2$)$. Others HMBC correlations between $\mathrm{H}-3\left(\delta_{\mathrm{H}} 3.95\right) / \mathrm{H}_{2}-24\left(\delta_{\mathrm{H}} 3.87\right.$, 3.73) and acetal carbon $\mathrm{C}-1^{\prime}$ indicated location of acetonide group binding between C-3 and C-24. Remaining hydroxy methylene group was assigned to be $\mathrm{C}-23$ by $\mathrm{HMBC}$ correlations between $\mathrm{H}_{2}-23$ $\left(\delta_{\mathrm{H}} 3.68,3.59\right)$ and $\mathrm{C}-3\left(\delta_{\mathrm{C}} 67.2\right) / \mathrm{C}-24\left(\delta_{\mathrm{C}} 65.0\right) / \mathrm{C}-5$ $\left(\delta_{C} 44.4\right) / C-4\left(\delta_{C} 40.0\right)$. Position of C-C double bond at C-12/C-13 and carbonyl group C-28 were confirmed by $\mathrm{HMBC}$ correlations between $\mathrm{H}-18\left(\delta_{\mathrm{H}} 2.51\right)$ and C-12 $\left(\delta_{\mathrm{C}} 129.3\right) / \mathrm{C}-13\left(\delta_{\mathrm{C}} 137.8\right) / \mathrm{C}-28\left(\delta_{\mathrm{C}} 183.4\right)$ And the HMBC correlations between $\mathrm{H}_{3}-29\left(\delta_{\mathrm{H}} 1.19\right)$ and $\mathrm{C}-18\left(\delta_{\mathrm{C}} 52.8\right) / \mathrm{C}-19\left(\delta_{\mathrm{C}} 73.1\right) / \mathrm{C}-20\left(\delta_{\mathrm{C}} 41.0\right)$ suggested the last oxygenated carbon to be $\mathrm{C}-19$. The presence of hydroxy group at C-19 was also well 


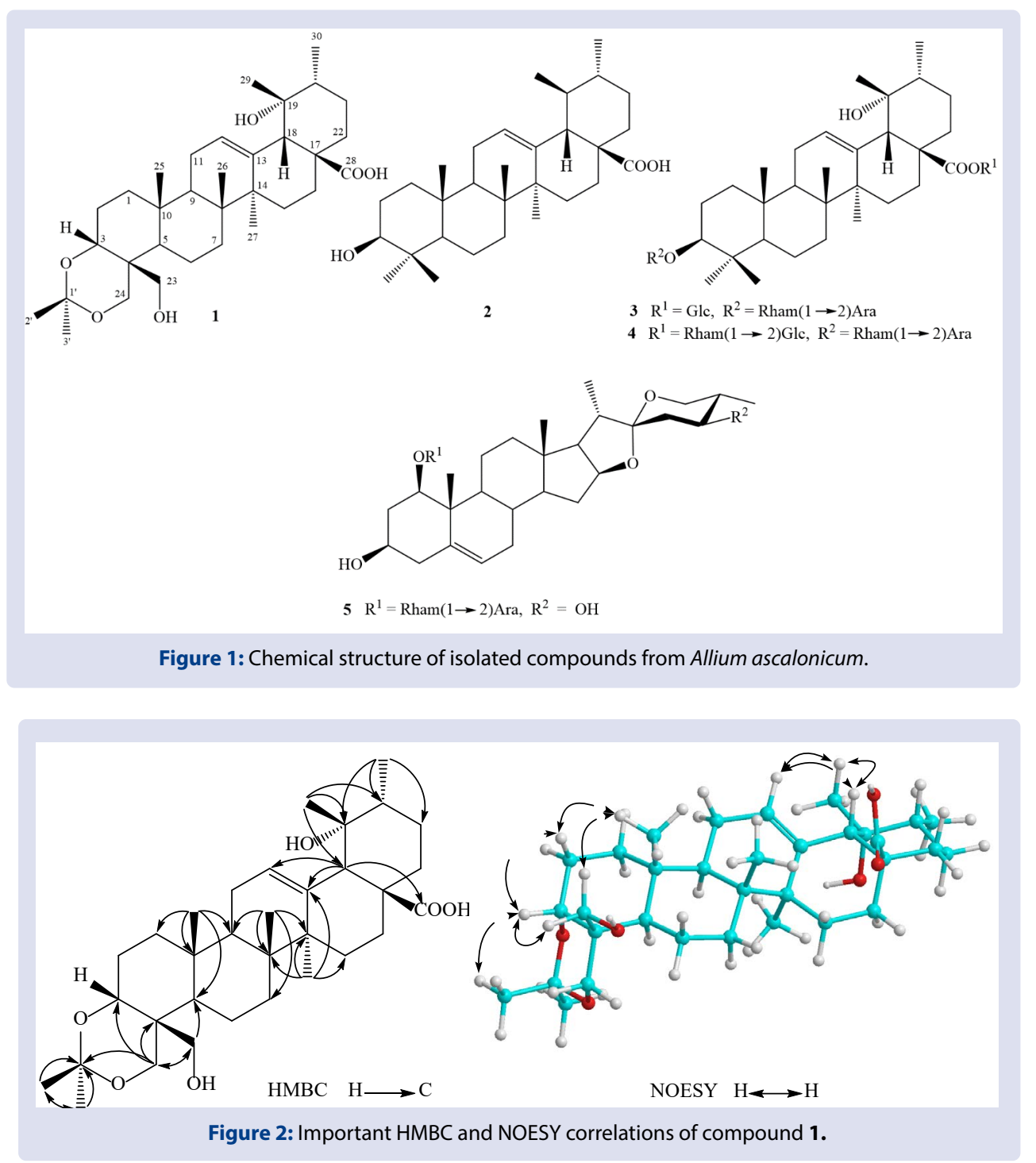

agreed with singlet multiplicity of $\mathrm{H}-18\left(\delta_{\mathrm{H}} 2.51\right)$ and $\mathrm{H}_{3}-29\left(\delta_{\mathrm{H}} 1.19\right)$. Finally, relative stereo chemistry of 1 was established by NOESY analysis (Figure 2). NOESY correlations between $\mathrm{H}_{3}-25\left(\delta_{\mathrm{H}} 0.91\right)$ and $\mathrm{H}-23\left(\delta_{\mathrm{H}} 3.68\right) / \mathrm{H}_{\text {axial }}-2\left(\delta_{\mathrm{H}} 1.80\right), \mathrm{H}_{\text {axial }}-2$ and $\mathrm{H}-3\left(\delta_{\mathrm{H}} 3.95\right)$ indicated that $\mathrm{H}_{3}-25, \mathrm{H}_{\text {axial }}-2, \mathrm{H}-3$, and $\mathrm{H}-23$ were close proximity and hence $\mathrm{C}-25$, $\mathrm{H}_{\text {axial }}-2, \mathrm{H}-3, \mathrm{C}-23$ were all $\beta$-orientations. The $\beta$-orientation (equatorial position) of $\mathrm{H}-3$ was also supported by its broad singlet signal $\left(\delta_{\mathrm{H}} 3.95\right)$ in the ${ }^{1} \mathrm{H}$-NMR spectrum. On the other hand, the NOESY correlations between $\mathrm{H}_{3}-29\left(\delta_{\mathrm{H}} 1.19\right)$ and $\mathrm{H}-18\left(\delta_{\mathrm{H}} 2.51\right) / \mathrm{H}-12\left(\delta_{\mathrm{H}} 5.33\right)$ suggested for $\beta$-orientations of $\mathrm{H}-18$ and methyl group $\mathrm{C}-29$, showing $\alpha$-orientation of hydroxy group at C-19. Consequently, structure of compound $\mathbf{1}$ was determined to be 3,24-acetonideclethric acid.

Other compounds were determined to be ursolic acid (2), ${ }^{6}$ randiasaponin IV (3), ${ }^{7}$ ilekudinoside W (4), ${ }^{8}$ (25S)-1 $\beta, 3 \beta, 24 \beta$-trihydroxyspirost-5-en 1-O- $\alpha$-L-rhamnopyranosyl- $(1 \rightarrow 2)$ - $\alpha$-L-arabinopyranoside $(5),{ }^{9}$ by the good agreement of their NMR spectral data with those reported in the literature.

The steroids, triterpenoids, and saponins from Allium species have been reviewed as potential antimicrobial activity., 10 Therefore, compounds 1-5 were evaluated their antimicrobial activity against three pathogenic microbial strains including Gram-positive bacteria (Staphylococcus aureus), Gram-negative bacteria (Escherichia coli), and yeast (Candida albicans). As shown in the Table 2, except compound 2, the tested compounds exhibited antibacterial activity against both Gram- positive (S. aureus) and Gram-negative (E. coli) with $\mathrm{IC}_{50}$ values in the range from $42.73 \pm 2.24$ to $117.12 \pm 4.93 \mu \mathrm{M}$. Saponins (3-5) displayed cytotoxic to all tested microbial strains with $\mathrm{IC}_{50}$ values in the range from $60.18 \pm 4.10$ to $95.71 \pm 3.86 \mu \mathrm{M}$. Among ursane-type triterpene (1-4), saponins exhibited better anti-microbial activity in comparison with the aglycone triterpene. The standard drugs chloramphenicol and fluconazole were used as positive control for antibacterial and antifungal test. Once again, these results confirmed that triterpenoid, steroid, especially the saponins are anti-microbial components from $A$. ascalonicum. Compound 1, a new derivative of ursolic acid presented better anti-bacterial activity than ursolic acid (2).

\section{MATERIALS AND METHOD}

\section{General experimental procedures}

Optical rotation was recorded on a Jasco P2000 polarimeter. NMR spectra were measured on a Bruker $500 \mathrm{MHz}$ spectrometer using TMS as an internal standard. HR-ESI-MS was acquired on an Agilent 6530 Accurate Mass Q-TOF LC/MS system. Column chromatography was performed using silica gel, reverse phase C-18, and diaion HP-20 resins. Thin layer chromatography was carried out using pre-coated silica gel $60 \mathrm{~F}_{254}$ and $\mathrm{RP}-18 \mathrm{~F}_{254 \mathrm{~S}}$ plates. The plates were visualized under UV radiation ( 254 and $365 \mathrm{~nm}$ ) and by spraying with aqueous $\mathrm{H}_{2} \mathrm{SO}_{4}$ solution (5\%) followed by heating with a heat gun. 


\section{Plant materials}

The bulbs of A. ascalonicum were collected in An Hai Commune, Ly Son island district, Quang Ngai Province, Vietnam in 2019. Its scientific name was identified by Dr. Do Thi Xuyen, Department of Biology, VNU University of Science, Vietnam National University, Hanoi. A voucher specimen (VNU181019) was deposited at the Herbarium of the VNU University of Science, Vietnam National University, Hanoi. The fresh bulbs were fermented under suitable temperature and humidity for a certain period of time to get the fermented ones.

\section{Isolation and extraction}

The dried powdered of fermented shallot A. ascalonicum $(5.0 \mathrm{~kg})$ was ultrasonically extracted with methanol for three times in room temperature (each $10 \mathrm{~L}, 30 \mathrm{~min}$ ). After removal of the solvent, methanol extract $(400 \mathrm{~g})$ was suspended in $3 \mathrm{~L}$ of water and then successively partitioned with dichloromethane, ethyl acetate to give corresponding extracts dichloromethane (ASD, $73 \mathrm{~g}$ ), ethyl acetate (ASE, $12 \mathrm{~g}$ ), and water layer (ASW). The ASD and ASE extract were combined and separated on a silica gel column, eluting with gradient system of $n$-hexane/acetone $(0-100 \%$ acetone) to give four fractions ASD1-ASD4. The ASD3 fraction was loaded on a RP-18 column and eluted with methanol/water $(3 / 1, \mathrm{v} / \mathrm{v})$ to give compounds $2(61 \mathrm{mg})$.
The ASD4 fraction was purified on a silica gel column chromatography, eluting with dichloromethane/acetone $(7 / 1, \mathrm{v} / \mathrm{v})$ to give compound 1 (14 mg). The water layer (ASW) was poured on a diaion HP-20 column chromatography, washed with water $(2 \mathrm{~L})$, and then eluted with methanol/water (stepwise, 25\%, 50\%, 75\%, 100\% methanol) to give four fractions ASW1-ASW4. Fraction ASW2 was separated on a silica gel column, eluting with dichloromethane/methanol (0-100\% methanol) to give six fractions ASW2A-ASW2F. Fraction ASW2D was also purified on a RP-18 column, eluting with acetone/water (5/2, $\mathrm{v} / \mathrm{v})$ to give compounds $3(27 \mathrm{mg})$ and $4(16 \mathrm{mg})$. Fraction ASW2C was separated on a silica gel column, eluting with dichloromethane/ methanol $(0-100 \%$ methanol) to give five fractions ASW3A-ASW3E. Fraction ASW3C was purified on a RP-18 column, eluting with methanol/water $(3 / 2, \mathrm{v} / \mathrm{v})$ to obtain compound $5(24 \mathrm{mg})$.

\section{3,24-acetonideclethric acid (1)}

White amorphous powder; $[\alpha]_{D}^{5}:-43.1(c$ 0.1, MeOH); HR-ESI-MS $m / z: 543.3691[\mathrm{M}-\mathrm{H}]^{-}\left(\right.$calcd for $\left.\mathrm{C}_{33} \mathrm{H}_{51} \mathrm{O}_{6}, 543.3686\right) ;{ }^{1} \mathrm{H}$ - and ${ }^{13} \mathrm{C}-\mathrm{NMR}$ spectral data are given in the Table 1.

\section{Antimicrobial assay}

Three microbial strains from American Type Culture Collection including Candida albicans ATCC 10231 (yeast), Escherichia coliATCC

Table 1: ${ }^{1} \mathrm{H}$ and ${ }^{13} \mathrm{C}$ NMR spectral data for compound 1.

\begin{tabular}{|c|c|c|}
\hline No. & $\delta_{c}^{a, b}$ & $\delta_{H}^{a, c}($ mult, $J$ in $\mathrm{Hz})$ \\
\hline 1 & 33.0 & $1.33(\mathrm{~m}) / 1.52(\mathrm{~m})$ \\
\hline 2 & 23.5 & $1.51(\mathrm{~m}) / 1.80(\mathrm{~m})$ \\
\hline 3 & 67.2 & 3.95 (br s) \\
\hline 4 & 40.0 & - \\
\hline 5 & 44.4 & $1.83(\mathrm{~m})$ \\
\hline 6 & 18.8 & $1.35(\mathrm{~m}) / 1.43(\mathrm{~m})$ \\
\hline 7 & 32.8 & $1.65(\mathrm{~m}) / 1.79(\mathrm{~m})$ \\
\hline 8 & 40.7 & - \\
\hline 9 & 46.9 & $1.78(\mathrm{~m})$ \\
\hline 10 & 36.4 & - \\
\hline 11 & 23.6 & $1.90(\mathrm{~m}) / 2.03(\mathrm{~m})$ \\
\hline 12 & 129.3 & 5.33 (br s) \\
\hline 13 & 137.8 & - \\
\hline 14 & 41.0 & - \\
\hline 15 & 27.9 & $1.02(\mathrm{~m}) / 1.69(\mathrm{~m})$ \\
\hline 16 & 25.9 & $1.26(\mathrm{~m}) / 1.65(\mathrm{~m})$ \\
\hline 17 & 47.7 & - \\
\hline 18 & 52.8 & $2.51(\mathrm{~s})$ \\
\hline 19 & 73.1 & - \\
\hline 20 & 41.0 & $1.38(\mathrm{~m})$ \\
\hline 21 & 25.3 & $1.56(\mathrm{~m}) / 2.50(\mathrm{~m})$ \\
\hline 22 & 37.5 & $1.64(\mathrm{~m}) / 1.79(\mathrm{~m})$ \\
\hline 23 & 64.4 & $3.59(\mathrm{~d}, 12.0) / 3.68(\mathrm{~d}, 12.0)$ \\
\hline 24 & 65.0 & $3.73(\mathrm{~d}, 12.0) / 3.87(\mathrm{~d}, 12.0)$ \\
\hline 25 & 15.5 & $0.91(\mathrm{~s})$ \\
\hline 26 & 17.0 & $0.69(\mathrm{~s})$ \\
\hline 27 & 24.4 & $1.26(\mathrm{~s})$ \\
\hline 28 & 183.4 & - \\
\hline 29 & 27.4 & $1.19(\mathrm{~s})$ \\
\hline 30 & 16.1 & $0.93(\mathrm{~d}, 6.8)$ \\
\hline $1^{\prime}$ & 98.7 & - \\
\hline $2^{\prime}$ & 20.5 & $1.40(\mathrm{~s})$ \\
\hline $3^{\prime}$ & 27.9 & $1.37(\mathrm{~s})$ \\
\hline
\end{tabular}

Measured in ${ }^{\text {a) }} \mathrm{CDCl}_{3}$, ${ }^{\text {b) }} 500 \mathrm{MHz},{ }^{\text {c) }} 125 \mathrm{MHz}$. Assignments were done by HMQC, HMQC, COSY, and NOESY experiments 
Table 2: Antimicrobial activity of compounds 1-5.

\begin{tabular}{cccc}
\hline \multirow{2}{*}{ Comp. } & \multicolumn{3}{c}{$\mathrm{IC}_{50}(\mu \mathrm{M})$} \\
\cline { 2 - 4 } & S. aureus & E. coli & C. albicans \\
\hline $\mathbf{1}$ & $102.62 \pm 2.07$ & $117.12 \pm 4.93$ & $>128$ \\
$\mathbf{2}$ & $>128$ & $>128$ & $>128$ \\
$\mathbf{3}$ & $88.21 \pm 4.84$ & $73.02 \pm 3.48$ & $89.49 \pm 2.24$ \\
$\mathbf{4}$ & $72.04 \pm 2.71$ & $60.18 \pm 4.10$ & $95.71 \pm 3.86$ \\
$\mathbf{5}$ & $67.98 \pm 3.64$ & $78.31 \pm 2.42$ & $93.81 \pm 4.52$ \\
Chlo & $7.11 \pm 0.24$ & $4.47 \pm 0.16$ & - \\
Fluc & - & - & $1.93 \pm 0.21$ \\
\hline
\end{tabular}

Chloramphenicol (Chlo) and fluconazole (Fluc) were used as positive control, (-): not tested.

25922 (Gram-negative bacterium), and Staphylococcus aureus ATCC 13709(Gram-positive bacterium) were used to evaluate antimicrobial activity. Assay was performed in 96 well plates by liquid-dilution method using resazurin as a redox indicator of microbial viability. ${ }^{11}$ In brief, each well containing $10 \mu \mathrm{L}$ of compounds and $190 \mu \mathrm{L}$ of microorganism suspension (bacteria inoculum $5 \times 10^{5} \mathrm{CFU} / \mathrm{mL}$ and yeast inoculum $5 \times 10^{3} \mathrm{CFU} / \mathrm{mL}$ ) was incubated at $37^{\circ} \mathrm{C}$ in $18 \mathrm{~h}$ for yeast and $20 \mathrm{~h}$ for bacteria. After addition of $10 \mu \mathrm{L}$ of resazurin $(0.1 \mathrm{mg} / \mathrm{mL})$, the microbial viability was assessed fluorimetrically $\left(\lambda_{\mathrm{ex}}=550 \mathrm{~nm}, \lambda_{\mathrm{em}} 590 \mathrm{~nm}\right)$ on a microplate reader (TecanGenios). The results were expressed in term of percent reduction of microorganism viability compared with control well and $\mathrm{IC}_{50}$ values were determined from dose-response curve.

\section{CONCLUSIONS}

Five compounds were isolated from the bulbs of A. ascalonicum. Their chemical structures were determined to be 3,24-acetonideclethric acid (1), ursolic acid (2), randiasaponin IV (3), ilekudinoside W (4), (25S)$1 \beta, 3 \beta, 24 \beta$-trihydroxyspirost-5-en $\quad 1$-O- $\alpha$-L-rhamnopyranosyl- $(1 \rightarrow 2)$ $\alpha$-L-arabinopyranoside (5). Compound 1 was a new ursane-type triterpene and exhibited weak anti-bacterial activity against $E$. coli and S. aureus strains. Saponins (3-5) displayed cytotoxic to E. coli, S. aureus, C. albicans microbial strains with $\mathrm{IC}_{50}$ values in the range from $36.62 \pm$ 1.88 to $101.99 \pm 3.17 \mu \mathrm{M}$.

\section{CONFLICTS OF INTEREST}

The authors declare that there is no potential conflicts of interest

\section{ACKNOWLEDGEMENT}

This research was financially supported by the Drug R\&D Center, Vietnam Military. Medical University, Hadong District, Hanoi, Vietnam.

\section{REFERENCES}

1. Sobolewska, D.; Michalska, K.; Podolak, I.; Grabowska, K., Steroidal saponins from the genus Allium. Phytochem Rev. 2016;15(1):1-35.

2. Rizwani, G. H.; Shareef, H., Genus Allium: the potential nutritive and therapeutic source. J Pharm Nutr Sci. 2011;1(2):158-65.

3. Lanzotti, V.; Scala, F.; Bonanomi, G., Compounds from Allium species with cytotoxic and antimicrobial activity. Phytochem Rev. 2014;13(4):769-91.

4. Lanzotti, V.; Bonanomi, G.; Scala, F., What makes Allium species effective against pathogenic microbes? Phytochem Rev. 2013;12(4):751-72.

5. Zhao, W.; Wolfender, J.-L.; Hostettmann, K.; Cheng, K.; Xu, R.; Qin, G. Triterpenes and triterpenoid saponins from Mussaenda pubescens. Phytochemistry. 1997;45(5):1073-8.

6. Castellon, I. L. A: Nazabadioko, L. V: Huong, D. T. M: Roseau N Bouthagane, N.; et al., Triterpenoid saponins from Symplocos lancifolia. J Nat Prod. $2011 ; 74(2): 163-8$.

7. Sahpaz, S.; Gupta, M. P.; Hostettmann, K., Triterpene saponins from Randia formosa. Phytochemistry. 2000;54(1):77-84.

8. Che, Y.Y.; Li, N.; Zhang, L.; Tu, P. F., Triterpenoid saponins from the leaves of Ilex kudingcha. Chin J Nat Med. 2011;9(1):22-5.

9. Kuroda, M.; Mimaki, Y.; Ori, K.; Sakagami, H.; Sashida, Y., Steroidal glycosides from the bulbs of Ornithogalum thyrsoides. J Nat Prod. 2004;67(10):1690-6.

10. Kyung, K. H., Antimicrobial properties of allium species. Curr Opin Biotechnol. 2012;23(2):142-7.

11. Cos, P.; Vlietinck, A. J.; Berghe, D. V.; Maes, L., Anti-infective potential of natural products: how to develop a stronger in vitro 'proof-of-concept'. J Ethnopharmacol. 2006;106(3):290-302. 


\section{GRAPHICAL ABSTRACT}

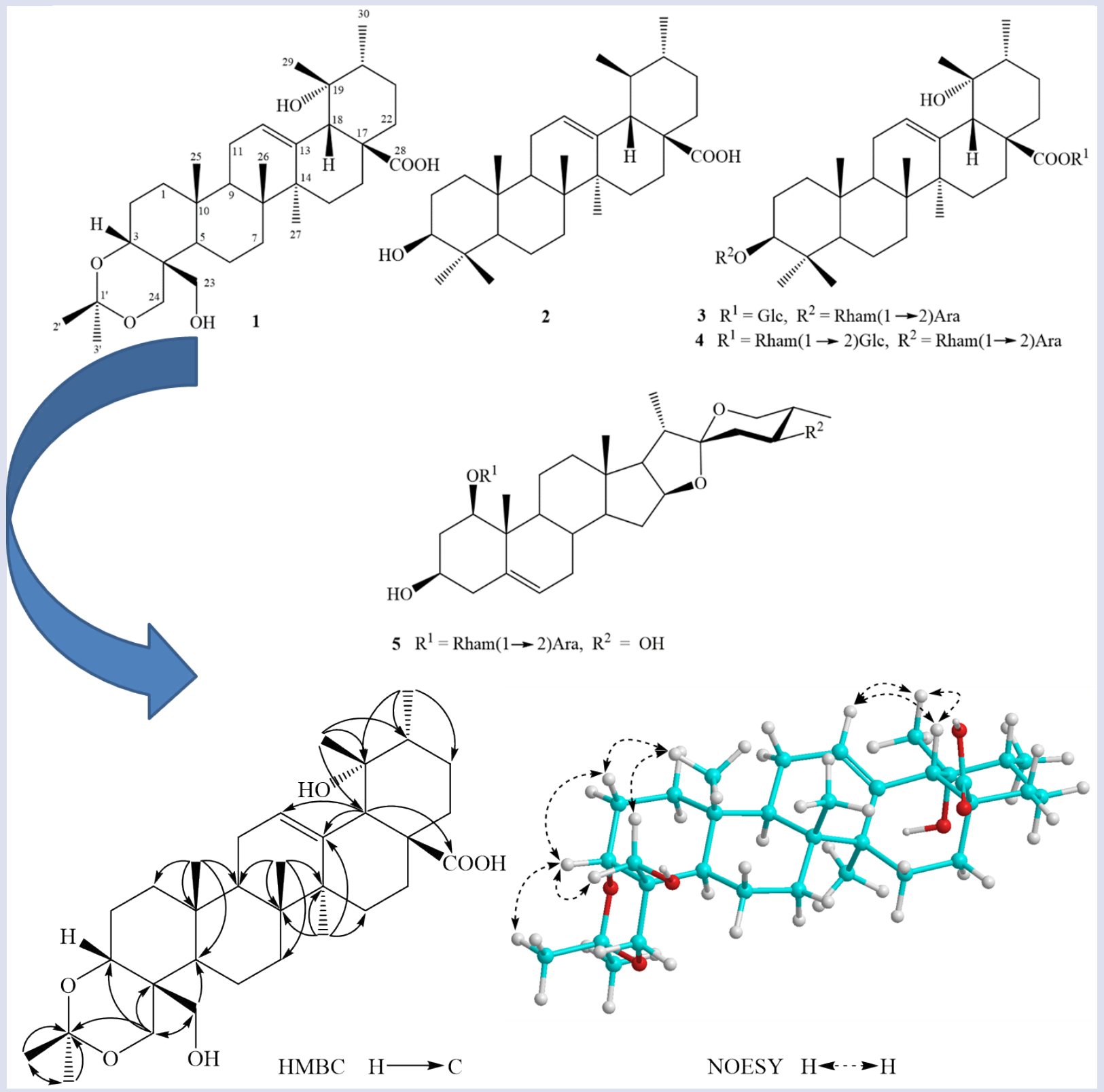

\section{SUMMARY}

3,24-acetonideclethric acid (1), a new ursane-type triterpene, and four known compounds including ursolic acid (2), randiasaponin

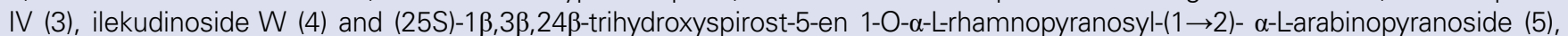
and were isolated from the fermented shallot Allium ascalonicum. Their structures were determined by analysis of HR-ESI-MS, NMR spectral data, as well as comparison with those reported in the literature. All of the saponins (3-5) exhibited antimicrobial activity against three strains Staphylococcus aureus, Escherichia coli, and Candida albicans with IC50 values in the range from $89.49 \pm 2.24$ to $95.71 \pm 3.86 \mu \mathrm{M}$. 


\section{ABOUT AUTHORS}

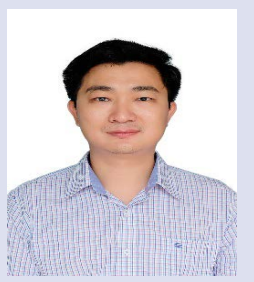

Nguyen Van Chuyen: is an Assistant Professor, Vice head, Department of Military Hygiene, VMMU.

Nguyen Hong Son: A Researcher of The Drug R\&D Center, VMMU.
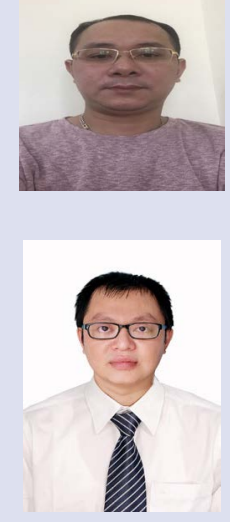

Nguyen Van Hien: A Researcher of The Drug R\&D Center, VMMU.

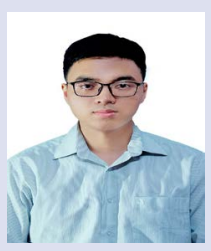

Ho Ba Ngoc Minh: A Researcher of the Research Center for Drug Manufacturing Applications, VMMU.

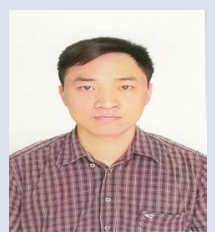

Dang Truong Giang: A Researcher of The Drug R\&D Center, VMMU.

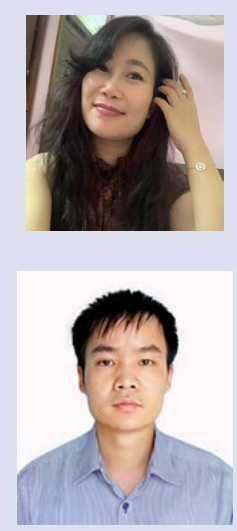

Ngo Thi Tuyet Mai: A Researcher of The Drug R\&D Center, VMMU.

Chu Van Men: Assistant Professor, Director, Clinical Trial and Bioequivalent Testing Centre, Institute of Biomedicine and Pharmacy, VMMU. 


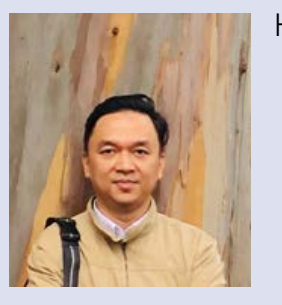

Ho Anh Son: Associate Professor, Vice Director of the Institute of Biomedicine and Pharmacy, VMMU.

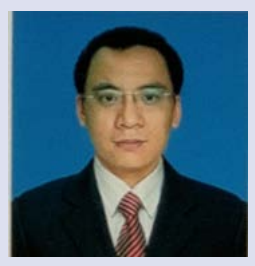

Vu Binh Duong: Associate Professor, Director of The Drug R\&D Center, VMMU.

Cite this article: Chuyen NV, Son NH, Hien PV, Giang DT, Minh HBN, Mai NTT, et al. A New Ursane-Type Triterpene from the Fermented Shallot Allium Ascalonicum. Pharmacog J. 2021;13(1): 01-07. 